Gazi University
Journal of Science
http://dergipark.gov.tr/gujs

\title{
Survey on the User Satisfaction with the Mass Housing Projects Led by District Municipality: Konya-Karatay Example
}

\author{
Betul HATIPOGLU SAHIN*(i), Aysegul TERECI \\ KTO Karatay University, Faculty of Fine Arts and Design, Department of Architecture, 42020, Konya, Turkey
}

\author{
Highlights \\ - User satisfaction survey related with mass housing projects built by the local government. \\ - 44 survey questions applied to 280 users. \\ - Effect of five determined factor groups on user satisfaction.
}

\begin{tabular}{l} 
Article Info \\
\hline \\
Received: 07 July 2020 \\
Accepted:26 Dec 2020 \\
Keywords \\
Mass housing \\
User satisfactions \\
Space analysis \\
Local government \\
Konya
\end{tabular}

\section{INTRODUCTION}

The house; the type of building created by human beings in order to meet their sheltering needs, still continues its evolution that has been going on for years. Along with the urbanization process, fictional changes occurred in new residential areas and changes were observed also in existing residential areas and spaces [1]. Especially the different production techniques used following the Industrial Revolution caused the business areas to shift to the cities, and the urban population has increased gradually as a result of migration [2]. With the increasing population, cities were not physically and socially ready for this situation, thus they faced with many problems such as shelter problems, lack of infrastructure and environmental problems [3]. The housing problem has then occurred in terms of both quality and quantity. In order to solve this problem, different applications have been performed in time [4].

Considering the historical process; it is seen that mass housing affects the planning decisions of cities in the world and in our country especially in the last two centuries. The concept of mass housing appeared in England firstly, then has led to the development of mass building production in Belgium, Germany and France. After World War II, mass housing production increased all over the world, and this situation played an important role in the development of high-tech mass production [5]. At this point, the policies in European countries differ from other developing countries. Although there are different practices among in 
European countries, a general perspective can be drawn. In social housings where production is provided by the state; it is observed that property rights are not granted and the tenancy system works systematically [6]. Social housing practices which aiming social cohesion, are seen as many different housing typologies such as row houses, back to back houses, single or twin houses, apartments [5].Social housing production started later than European countries, still continues rapidly In developing countries. However, many adverse situations such as insufficiency of the housing stock and inability of poor people pay for the houses still continues [7]. In developed and developing countries different applications are observed both in new building applications and in utilization of existing housing stock. Many developed countries have preferred to utilize the existing housing stock by preserving and improving the quality of the existing houses. Furthermore in the design of new buildings; the physical and psycho-social needs of the user, satisfaction with the space and content have all been taken into consideration. However, in many developing countries, due to the physical deficiencies of the building stock, the buildings are demolished, instead new housing projects that do not reflect the geographical texture, culture and distinctness of the region are produced. Since the user is not included in any stage of the design phase, these projects do not meet also sufficiently life quality and needs of the users.

The development of industrial construction systems ensured rapid and economic production of houses. Mass housing production was first seen in England and then spread all over Europe. In Turkey mass housing and social housing practices appear to be two concepts mixed with each other. In Turkey public institutions are involved in the housing production organization, but mass housing itself is a commercial concept. For this reason the equivalents of these concepts are confused [8].

Examining the mass housing process in Turkey, we see that mass housing was developed as a solution to rapid urbanization problem. Rapid urbanization process in Turkey has begun since the 1950s. With the rapid migration from the rural areas and with the consequent unorganized urbanization, the cities have become "monstrous cities" as citied by Tekeli [9]. Especially in big cities, the concept of "shanty houses" emerged as the housing problem gradually increased [10]. With the continuous increase in the population in large cities receiving large immigration, illegal settlements and shanty houses have gradually increased due to the lack of adequate housing for the lower income level [11]. The government over years has tried to take measures against unorganized urbanization and prevent this situation by making housing policies.

In this respect, the "Law No. 2985 on Mass Housing", which entered into force in 1984, and the establishment of TOKI (Mass Housing Administration) are the major steps taken for the realization of mass housing projects. Until 2002, the institution was not able to achieve the goal of producing low cost housing in a short time. With the Emergency Action Plan, which was put into operation in 2002, production of 250 thousand residences was targeted in four years. Moreover, in 2005, with the Law No.5393 on Municipality, local administrations were entrusted with duties such as building mass housing, selling, renting, purchasing and expropriation. With this law, municipalities also started to implement mass housing. TOKİ has carried out many mass housing projects for low and middle income groups and with these projects it has changed the appearance and structure of the cities. As of 03.01.2018, it has built 817,089 houses in 81 provinces [12]. At this point, the quality problem in mass housing led by both TOKI and local administrations brought along many discussions, the satisfaction levels of the users for sure will offer an insight into these discussions.

\section{MEASUREMENT OF USER SATISFACTION IN MASS HOUSING}

The user satisfaction, as an evaluation of the user after use, is a multidimensional concept shaped in line with the individual's perception beyond the physical standards. When the concept of "satisfaction from the house and its surroundings", which is accepted as a sub-parameter of the satisfaction concept is examined, it is seen that there are different parameters. The satisfaction with the housing area is related to many variables such as the condition of the houses, the security of the housing area, the quality of the houses, being a liveable place, and being pleased with the neighbours [13]. For this reason, in measuring the level of satisfaction, variables related only with space are not sufficient.

The degree of satisfaction can change depending on the person, time, social situation, educational level and expectations. Anthony vd. in their study identified the variables that can be used in the examination of 
residential area satisfaction as; the appearance of the building complex, management, maintenance, security, the homogeneity of the neighbours, the quality of the areas in the house, the open area facilities around the buildings [14]. In addition, it was observed that residential user satisfaction is related also with family structure and marital status, that user characteristics have a significant effect on the satisfaction with the house and its environment [15].

Türkoğlu, in his study to measure the satisfaction of residential users in Istanbul conducted with the participation of 480 users, identified 6 factor groups: the size and physical conditions of the house, access to the city centre, workplace, hospital, shopping areas and municipal services, availability and maintenance of social, recreational and educational services, social and physical environmental problems, climate control of the house and satisfaction with neighbours [16]. In the studies of Je \& Lee \& Chong \& Shin 5 factors were found to have an impact on user satisfaction; infrastructure (equipment, harmony with life, health, pleasure, safety), visual factors (view, form, visual balance), use of space (circulation, space functions, space efficiency), social environment (environment, social relations), management (management, security, economic value). In their study, the use of the space was found to be the most influential factor on satisfaction. The plan and the positioning of the buildings with each other were important parameters [17]. Gür and Dostoğlu to measure user satisfaction identified 7 factors in their study conducted in Bursa; social facilities and open spaces, environmental characteristics, physical features of the house, accessibility-transport, security, climate control of the house, neighbourhood relations [18]. Berköz determined 12 factor groups in his research in Istanbul and these are; satisfaction from open and green areas, security, social and neighbourhood relations, accessibility, suitability with user status, accessibility to open areas, satisfaction from social and public services, maintenance of the surrounding environment, access to educational facilities, density of buildings and traffic, access to health facilities, satisfaction with public-transport [19].

This study, benefitting from the scales used in literature and the results achieved in the previous researches, is outlined of the following main headings; the physical characteristics of the house, open-green areas, accessibility, comfort conditions and social-neighbourhood relations. In this study; in identifying the physical characteristics of the house factor, the study of Türkoğlu (1997:60) and Gür and Dostoğlu (2010:146); in identifying the factor of open-green areas Berköz (2008: 122), Gür and Dostoğlu (2010: 146), Anthony and ark. ; in determining the accessibility factor Gür and Dostoğlu (2010: 146); in determining the factor of comfort conditions, Je \& Lee \& Chong \& Shin (2007: 900), Türkoğlu (1997: 60); in identifying the social neighbourhood relations factor, the studies of Türkoğlu (1997: 60) and Berköz (2008: 122) were used. In the questionnaire on measuring satisfaction; 12 closed-end, 31 1-5 likert scale questions (1: Strongly disagree, 2: Disagree, 3: Neither agree or disagree, 4: Agree, 5: Strongly agree) were asked. In addition, to measure the relation of interior spaces with each other, 6 questions with answer options; "far-normal-close" were asked.

\section{SCOPE AND METHOD OF THE RESEARCH}

The study has drawn a general perspective aimed at measuring user satisfaction in mass housing projects led by the municipality. It is important that the user is included in the design of the space where the user lives and that the opinions of the user contribute to the designs in future in mass housing production which is increasing day by day with the effect of environmental, social and political components, satisfaction of the individuals changes in line with the environmental scale, context, changing time parameters. In this context, differentiated times and conditions shows divergent effects on users. At this point, satisfaction studies; It aims to evaluate the policies from local to national and international scale and to generate ideas for decision makers [20]. Revealing the positive and negative opinions in the produced houses is very important for feedback mechanism to function properly. Determining the satisfaction levels of the users who use and experience the space in the mass housing projects produced with the leadership of local administrations having full knowledge of the social structure of the region, will provide insight for future studies.

Konya city, as the chosen area of this study; is the seventh largest city in Turkey and due to its geographical location, its industrial potential is high and it offers many socio-cultural opportunities. For these reasons, 
urban life also in Konya has become more attractive, even though it has a great agricultural potential in rural areas. As a result of the migrations to Konya, settlement areas have been formed in the city boundaries and these areas have preserved their unique rural housing quality [21]. However, with the transformations, these houses are gradually replaced by mass housing.

From this point of view, Konya province, Karatay district where mass housing projects are designed and implemented very quickly, was chosen as the research area. Konya-Karatay district is a region where change is quite intense. The way of housing production, led by the municipality in the region, is quite similar to TOKİ applications. This selected region has been deemed appropriate for the research due to its proximity to the city centre, its easy accessibility and its increasing number of users, day by day. The District Municipality set the target of building 11,428 houses through 22 mass housing projects between 2004-2015. Until today around 6900 houses have been delivered. The total population in these apartments is about 28 thousand people.

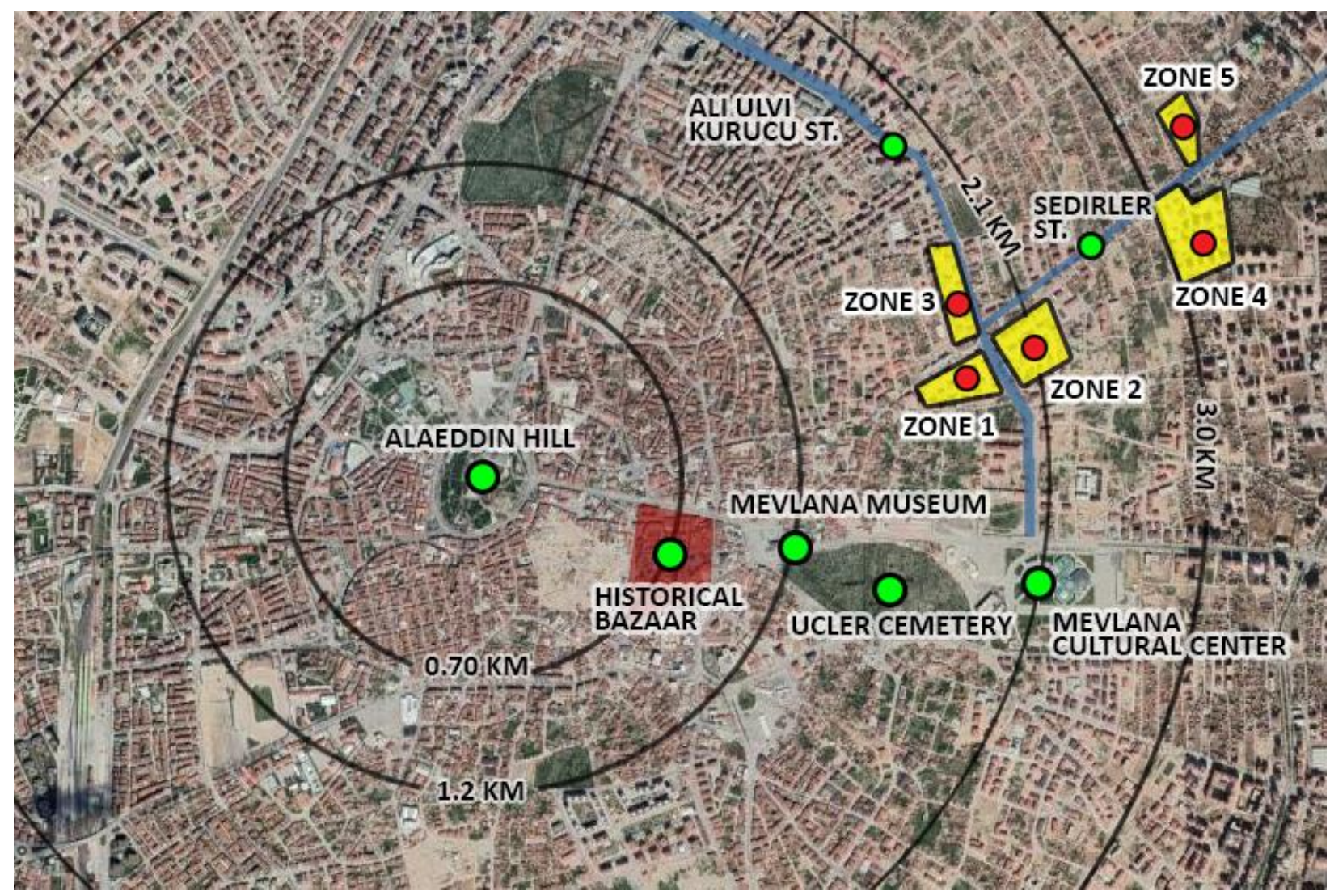

Figure 1. Location of the Study Area in Konya Province

In order to understand the general structure in the region, 5 housing areas close to each other with their locations and construction years were chosen as sample. Mass housing applications selected for the field study were carried out under the leadership of local administrations in accordance with the "Municipality Law" No.5393. All the existing houses in these areas were demolished and in their place at least 10 blocks 6-storey blocks were designed. The construction of the 5 mass housing selected in the study started between 2005-2010, and the construction works in 4 of them continue in some stages during this research.

The study area is a region where mass housing applications led by Karatay Municipality are quite intense. The existing houses in the areas where the mass housing is planned are demolished and the lands of the right holders are purchased in return for the floor. This area forms the boundary of the Mevlana-Mevlâna Cultural Centre axle which is close to the city centre and is an important tourist place due to its historical and cultural heritage. Therefore, a rapid urban transformation was needed in this region through the work of district municipality. In determining the study area, this region where transformation is needed under the leadership of District Municipality was preferred. As seen in Figure 1, all 5 mass housing projects built by 
the district municipality in the area between Ali Ulvi Kurucu Street and Sedirler Street, an important part of the existing tissue, were included in this study. Figure 2 shows the urban texture before the demolition.
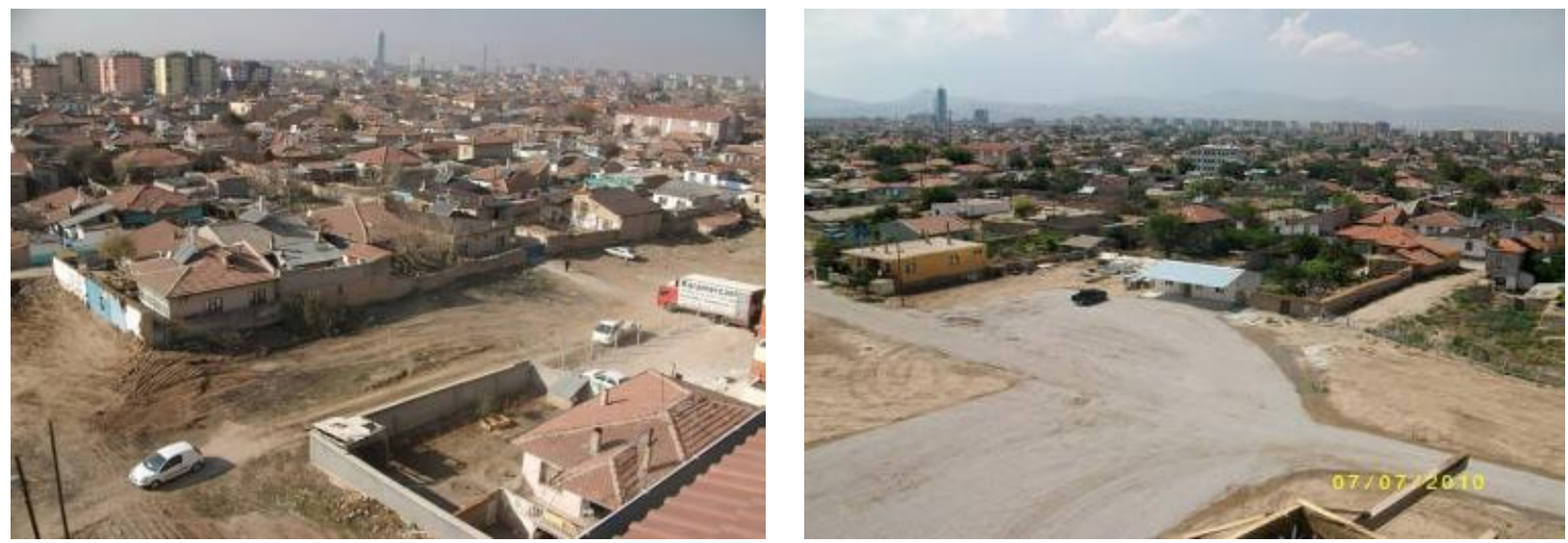

Figure 2. Photographs showing the texture of the work area before demolition [22]

In Figure 3, the apartments produced after demolitions are shown. Sufficient space was not given to green and social areas in the campus settlements which were produced as type projects. The space between the buildings was often designed even narrower than it was in the old single-storey buildings.
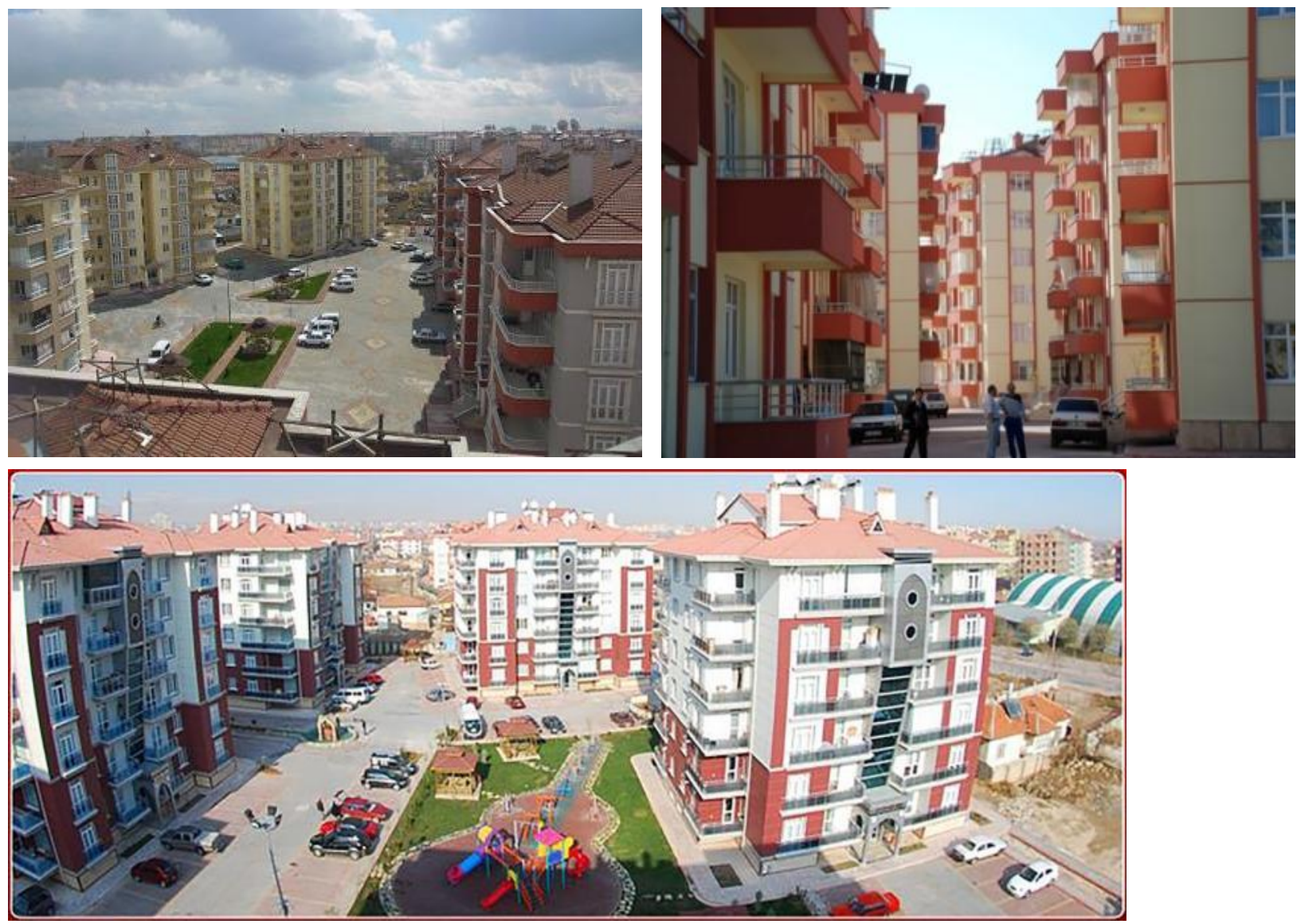

Figure 3. General View of Mass Housing in the Study Area

For 5 mass housing area selected as the research area, stratified sampling was used as the sampling technique and proportional distribution was ensured in creating the sample volume. It was decided to have a sample volume of 280 with a tolerable sampling error of $5 \%$ and a $95 \%$ confidence interval from the main mass group of 1752 residences. Accordingly, 280 users were randomly selected from the area and a questionnaire was 
applied. Table 1 shows the proportional distribution of the sample size according to number of houses in the selected areas.

Table 1. Proportional distribution of sample volume to mass housing areas

\begin{tabular}{|l|l|l|}
\hline Mass Housing & Total apartments & Its impact on the sample volume \\
\hline 1. Mass housing area & 408 Apartments & 65 Apartments \\
\hline 2. Mass housing area & 504 Apartments & 81 Apartments \\
\hline 3. Mass housing area & 312 Apartments & 50 Apartments \\
\hline 4. Mass housing area & 384 Apartments & 61 Apartments \\
\hline 5. Mass housing area & 144 Apartments & 23 Apartments \\
\hline TOTAL & 1752 Apartments & 280 Apartments \\
\hline
\end{tabular}

In the research, physical, social, financial and psychological parameters were chosen as factors determining the satisfaction. For this purpose, 44 questions were asked to the participants and the answers were evaluated in SPSS Statistics 20 program. The most important aim of data analysis is to reveal the satisfaction of users with their house and its surrounding environment which is related with many independent and dependent variables. Within the scope of analysis; frequency tables, reliability analysis, factor analysis, variance analysis, t-test and regression analysis were used.

\section{EXAMINING USER SATISFACTION IN MASS HOUSING AREAS}

When applying factor analysis to the question group consisting of 28 articles in the questionnaire, articles with factor loads over 0.30 were taken into consideration. As seen in Table 2, as a result of factor analysis, 5 factor groups were formed. The five factors obtained as a result of the analysis explains $65.03 \%$ of the total variance. In general, satisfaction appears to be related with the quality of the residential settlement. According to the result statistics, the first factor explains $18.28 \%$ of the total change (variance) of 28 variables. The factor which comes first is the physical characteristics of the house. This factor is followed by accessibility, opengreen areas, comfort conditions and social-neighbourhood relations.

Table 2. Factor groups related to the house and its surroundings

\begin{tabular}{|c|c|c|c|}
\hline FACTORS & ARTICLES & $\begin{array}{l}\text { FACTOR } \\
\text { LOAD }\end{array}$ & VARIANCE \\
\hline \multirow{9}{*}{$\begin{array}{l}\text { The physical } \\
\text { characteristics } \\
\text { of the house }\end{array}$} & $\begin{array}{l}\text { The number of rooms in my house is } \\
\text { sufficient. }\end{array}$ & ,789 & \multirow[t]{9}{*}{18,287} \\
\hline & $\begin{array}{l}\text { The size of the sitting room in my house is } \\
\text { sufficient. }\end{array}$ & ,857 & \\
\hline & $\begin{array}{l}\text { The size of the living room in my house is } \\
\text { sufficient. }\end{array}$ & ,789 & \\
\hline & $\begin{array}{l}\text { The size of the kitchen in my house is } \\
\text { sufficient. }\end{array}$ & 825 & \\
\hline & $\begin{array}{l}\text { The size of the bedroom in my house is } \\
\text { sufficient. }\end{array}$ & ,733 & \\
\hline & $\begin{array}{l}\text { The size of the bathroom - wc in my house is } \\
\text { sufficient. }\end{array}$ & ,733 & \\
\hline & $\begin{array}{l}\text { The size of the entrance hall-vestibule in my } \\
\text { house is sufficient. }\end{array}$ & ,630 & \\
\hline & The plan-design of my house is functional. & 672 & \\
\hline & $\begin{array}{l}\text { The size of the storage places in my house is } \\
\text { sufficient. }\end{array}$ &, 554 & \\
\hline \multirow[t]{3}{*}{ Accessibility } & I can go to the city centre from my house. & ,796 & \multirow[t]{3}{*}{13,282} \\
\hline & $\begin{array}{l}\text { I can go to my friends and relatives from my } \\
\text { house. }\end{array}$ & 815 & \\
\hline & $\begin{array}{l}\text { I can go to school/ education institutions from } \\
\text { my house. }\end{array}$ &, 814 & \\
\hline
\end{tabular}




\begin{tabular}{|c|c|c|c|}
\hline & $\begin{array}{l}\text { I can go to health care institutions from my } \\
\text { house. }\end{array}$ & ,801 & \\
\hline & $\begin{array}{l}\text { I can go to trade centre in my district from } \\
\text { my house. }\end{array}$ & 814 & \\
\hline \multirow[t]{6}{*}{$\begin{array}{l}\text { Open-green } \\
\text { areas }\end{array}$} & $\begin{array}{l}\text { I am pleased with the surroundings of my } \\
\text { house in general. }\end{array}$ & ,668 & \multirow[t]{6}{*}{13,069} \\
\hline & Green area around my house is sufficient. & ,791 & \\
\hline & $\begin{array}{l}\text { Play ground and resting areas around my } \\
\text { house is sufficient }\end{array}$ & ,841 & \\
\hline & $\begin{array}{l}\text { Car parking spaces around my house is } \\
\text { sufficient }\end{array}$ & ,747 & \\
\hline & The view from my house is nice in general. & ,721 & \\
\hline & $\begin{array}{l}\text { The distance between the buildings is } \\
\text { sufficient. }\end{array}$ & ,668 & \\
\hline \multirow{4}{*}{$\begin{array}{l}\text { Comfort } \\
\text { conditions }\end{array}$} & My house gets sufficient daylight. & ,755 & \multirow[t]{4}{*}{10,806} \\
\hline & $\begin{array}{l}\text { Ventilation in my house is sufficient in } \\
\text { general. }\end{array}$ & ,729 & \\
\hline & My house is heated sufficiently. & 860 & \\
\hline & $\begin{array}{l}\text { My house is sufficiently insulated against } \\
\text { cold. }\end{array}$ & 860 & \\
\hline \multirow{3}{*}{$\begin{array}{l}\text { Social-and } \\
\text { neighbourhood } \\
\text { relations }\end{array}$} & $\begin{array}{l}\text { I am pleased with my neighbours living in my } \\
\text { building. }\end{array}$ & 884 & \multirow[t]{3}{*}{9,723} \\
\hline & $\begin{array}{l}\text { I am pleased with neighbourhood relations in } \\
\text { my building. }\end{array}$ & ,898 & \\
\hline & I am pleased in general with social relations. & 828 & \\
\hline
\end{tabular}

\section{FINDINGS AND DISCUSSION}

\subsection{Demographic Findings}

As stated in Table 3, in the study in which 280 people participated, $53.6 \%$ of the participants are male and $46.4 \%$ are female users. Of the 280 people who participated in the study, 83 high school graduates were the group that most affected the survey. In the survey on ownership of the house, it is observed that house ownership is quite high with a $68.6 \%$ ratio. In the survey on the social security of the users, it is observed that they are affiliated with the Social Security Institution at the rate of 59.6\%. In the analysis of the monthly income of the users, it is seen that the user group with a monthly income in the range of minimum wage and over $1000 \mathrm{TL}$ occupies a ratio of $38.6 \%$. Then comes the group with the minimum wage. In the analysis of the users' owning another house, it is found out that 232 people do not have any other house. The apartment resulted to have the highest rate in the analysis of the type of residence that users lived before living in mass housing. Then comes the single-storey house, residence campus and shanty house.

Table 3. General characteristics features of the participants

\begin{tabular}{llll}
\hline Characteristics of the user & Sub Group & Frequency & Percentage \\
\hline Gender & Male & 150 & 53,6 \\
\cline { 2 - 4 } & Female & 130 & 46,4 \\
\hline $\begin{array}{l}\text { Age Range } \\
\text { *Age range was obtained } \\
\text { based on the data of Turkish } \\
\text { Statistical Institute. }\end{array}$ & $18-24$ & 26 & 9,3 \\
\hline Educational Status & $\mathbf{2 5 - 4 4}$ & $\mathbf{1 6 5}$ & $\mathbf{5 8 , 1}$ \\
\cline { 2 - 4 } & $45-64$ & 34 & 12,1 \\
\cline { 2 - 4 } & $65-84$ & 51 & 18,2 \\
\hline & Analphabetic & 5 & 1,8 \\
\cline { 2 - 4 } & Literate & 22 & 7,9 \\
\cline { 2 - 4 } & Primary school graduate & 26,8 \\
\cline { 2 - 4 } & $\begin{array}{l}\text { Secondary school } \\
\text { graduate }\end{array}$ & 40 & 14,3 \\
\hline
\end{tabular}




\begin{tabular}{|c|c|c|c|}
\hline & High school graduate & 82 & 29,3 \\
\hline & $\begin{array}{l}\text { University }- \text { academy } \\
\text { graduate }\end{array}$ & 52 & 18,6 \\
\hline & Postgraduate & 3 & 1,1 \\
\hline \multirow[t]{4}{*}{ Profession } & Labourer & 78 & 27,9 \\
\hline & Civil servant & 53 & 18,9 \\
\hline & Self-employment & 34 & 12,1 \\
\hline & Other & 51 & 18,2 \\
\hline \multirow[t]{5}{*}{ Work status } & Working full time & 126 & 45 \\
\hline & Working part time & 15 & 5,4 \\
\hline & House wife & 79 & 28,2 \\
\hline & Retired & 45 & 16,1 \\
\hline & Unemployed & 11 & 3,9 \\
\hline \multirow{9}{*}{$\begin{array}{l}\text { Number of individuals } \\
\text { living in the house }\end{array}$} & 1 Person & 5 & 1,8 \\
\hline & 2 Persons & 28 & 10,0 \\
\hline & 3 Persons & 47 & 16,8 \\
\hline & 4 Persons & 93 & 33,2 \\
\hline & 5 Persons & 62 & 2,1 \\
\hline & 6 Persons & 29 & 10,4 \\
\hline & 7 Persons & 10 & 3,6 \\
\hline & 8 Persons & 4 & 1,4 \\
\hline & 9 Persons & 1 & 0,4 \\
\hline \multirow[t]{2}{*}{ House Ownership } & House owner & 192 & 68,6 \\
\hline & Tenant & 88 & 31,4 \\
\hline \multirow[t]{5}{*}{ Social Security } & $\begin{array}{l}\text { SSK - Social Insurance } \\
\text { Institution }\end{array}$ & 167 & 59,6 \\
\hline & State Retirement Fund & 55 & 19,6 \\
\hline & $\begin{array}{l}\text { Social Security } \\
\text { Organization for Artisans } \\
\text { and the Self-Employed }\end{array}$ & 28 & 8,9 \\
\hline & None & 21 & 7,5 \\
\hline & Other & 11 & 3,9 \\
\hline \multirow{5}{*}{ Monthly Income } & Below minimum wage & 15 & 5,4 \\
\hline & Minimum wage & 73 & 26,1 \\
\hline & $\begin{array}{l}\text { Over minimum wage - } \\
\text { over } 1000 \mathrm{TL}\end{array}$ & 108 & 38,6 \\
\hline & $\begin{array}{l}\text { Over minimum wage - } \\
\text { over } 2000 \mathrm{TL}\end{array}$ & 53 & 18,9 \\
\hline & $\begin{array}{l}\text { Over minimum wage - } \\
\text { over } 3000 \mathrm{TL}\end{array}$ & 29 & 10,4 \\
\hline \multirow{2}{*}{$\begin{array}{l}\text { Ownership of another } \\
\text { apartment }\end{array}$} & Yes & 48 & 17,1 \\
\hline & No & 232 & 82,9 \\
\hline \multirow[t]{2}{*}{ Payments } & Yes & 94 & 48,96 \\
\hline & No & 98 & 51,04 \\
\hline \multirow[t]{4}{*}{ Previous Residence } & Shanty house & 21 & 7,5 \\
\hline & Single-storey house & 89 & 31,8 \\
\hline & Apartment & 134 & 47,9 \\
\hline & Residence campus & 35 & 12,5 \\
\hline
\end{tabular}

\subsection{Findings Gained from Comparison Among Factors}

In this part of the study, a t-test was performed to measure whether the averages of two independent groups were statistically significant. According to the t-test results, there was a difference between the male and female groups' satisfaction levels with the factors of physical characteristics of the house and the open-green areas. As it is seen in Table 4, the satisfaction levels of male users are higher in these two factor groups than female users. According to the questionnaire results, the satisfaction level of female participants in the physical space characteristics and the open-green area factors is lower than the male participants. While 
female participants who spend all their time at home face more and more problems with the house and its surroundings, male participants spending only evening time in their house may not be able to notice these problems. For this reason, it is an expected result that the female participants' satisfaction, especially in factors such as space size, functionality and sufficiency of open-green areas is lower than male participants.

Table 4. T-Test Results of Factor Groups According to the Gender Variable

\begin{tabular}{lllll}
\hline Factor Groups & $\begin{array}{l}\text { Female } \\
(\mathbf{1 3 0} \\
\text { persons })\end{array}$ & $\begin{array}{l}\text { Male } \mathbf{( 1 5 0} \\
\text { persons })\end{array}$ & $\mathbf{p}$ & $\mathbf{t}$ \\
\hline $\begin{array}{l}\text { Physical } \\
\text { characteristics of } \\
\text { the house }\end{array}$ & $\mathbf{3 , 3 7 5}$ & $\mathbf{3 , 5 9 9}$ & $\mathbf{0 , 0 4 8}$ & $\mathbf{1 , 9 7 1}$ \\
\hline $\begin{array}{l}\text { Open-green areas } \\
\text { Accessibility }\end{array}$ & $\mathbf{2 , 8 3 5 9}$ & $\mathbf{3 , 0 9 5 6}$ & $\mathbf{0 , 0 4 3}$ & \\
\hline $\begin{array}{l}\text { Comfort } \\
\text { conditions }\end{array}$ & 3,0938 & 3,2973 & 0,129 & $\mathbf{2 , 0 3 6}$ \\
\hline $\begin{array}{l}\text { Social- } \\
\text { neighbourhood } \\
\text { relations }\end{array}$ & 3,6192 & 3,5017 & 0,379 & $-0,880$ \\
\hline
\end{tabular}

The second t-test examined whether there was a significant difference in the level of satisfaction of the house owners and tenants with the factors. According to the results shown in Table 5, the satisfaction level of the house owners with physical space characteristics factor is higher than the tenants. 150 of the 192 house owners participating in the study have no other residence. For this reason, the satisfaction level of the house owners in the physical space characteristics factor resulted higher than 88 tenants' satisfaction level. House owners who do not own another house are more satisfied with their apartment than the tenants who have many alternatives to change their house. This analysis shows that there is a difference in the satisfaction levels of the house owners and tenants.

Table 5. T-Test Results of Factor Groups According to the Ownership-Tenant Variable

\begin{tabular}{lcccc}
\hline Factor Groups & $\begin{array}{l}\text { Owner of } \\
\text { the house } \\
(\mathbf{1 9 2} \\
\text { persons) }\end{array}$ & $\begin{array}{l}\text { Tenant } \\
\mathbf{8 8} \\
\text { persons) }\end{array}$ & $\mathbf{p}$ & $\mathbf{t}$ \\
\hline $\begin{array}{l}\text { Physical characteristics of the } \\
\text { house }\end{array}$ & $\mathbf{3 , 6 0 0}$ & $\mathbf{3 , 2 6 6}$ & $\mathbf{0 , 0 0 8}$ & $\mathbf{- 2 , 6 6}$ \\
\hline Open-green areas & 2,987 & 2,948 & 0,783 & $-0,27$ \\
\hline Accessibility & 3,137 & 3,345 & 0,149 & 1,446 \\
\hline Comfort conditions & 3,566 & 3,534 & 0,822 & $-0,22$ \\
\hline Social-neighbourhood relations & 3,670 & 3,393 & 0,076 & $-1,78$ \\
\hline
\end{tabular}

In the study, in order to determine the difference between groups by comparing them with each other, variance analysis was performed. This type of method is applied when there are more than two groups. In the variance analysis aimed at measuring the relation between educational status and level of satisfaction with the factors, a significant difference was found in the accessibility factor. As it is seen in Table 6, secondary school graduates have higher satisfaction level compared to other user groups. 
Table 6. Variance Analysis Results of the Factor Groups According to the Educational Status

\begin{tabular}{|c|c|c|c|c|c|c|c|c|c|}
\hline Factors & Analphabetic & Literate & $\begin{array}{l}\text { Primary } \\
\text { school } \\
\text { graduate }\end{array}$ & $\begin{array}{l}\text { Secondary } \\
\text { school } \\
\text { graduate }\end{array}$ & $\begin{array}{l}\text { High } \\
\text { school } \\
\text { graduate }\end{array}$ & $\begin{array}{l}\text { University } \\
\text { academy } \\
\text { graduate }\end{array}$ & Postgraduate & $\mathbf{p}$ & $\mathbf{F}$ \\
\hline $\begin{array}{l}\text { Physical } \\
\text { characteristics } \\
\text { of the house }\end{array}$ & 3,60 & 3,45 & 3,387 & 3,68 & 3,65 & 3,281 & 3,125 & 0,290 & 1,233 \\
\hline $\begin{array}{l}\text { Open-green } \\
\text { areas }\end{array}$ & 2,86 & 3,16 & 2,95 & 3,20 & 2,95 & 2,80 & 1,83 & 0,302 & 1,208 \\
\hline Accessibility & 2,72 & 3,18 & 3,01 & 3,65 & 3,30 & 3,08 & 2,13 & 0,038 & 2,266 \\
\hline $\begin{array}{l}\text { Comfort } \\
\text { conditions }\end{array}$ & 3,80 & 3,62 & 3,36 & 3,71 & 3,61 & 3,58 & 3,50 & 0,72 & 0,613 \\
\hline $\begin{array}{l}\text { Social- } \\
\text { neighbourhood } \\
\text { relations }\end{array}$ & 3,06 & 3,12 & 3,66 & 3,68 & 3,60 & 3,59 & 3,77 & 0,572 & 0,799 \\
\hline
\end{tabular}

In the post-hoc test measuring the relation between work status and level of satisfaction with the factors, there was a significant difference in the social-neighbourhood relations factor. According to Table 7, it is observed that the level of satisfaction of the housewives is higher than the other user groups, and the level of satisfaction of the full-time workers is the lowest.

Table 7. Variance Analysis Results of Factor Groups According to Work Status Variable

\begin{tabular}{lllllllc}
\hline Factors & $\begin{array}{l}\text { Working } \\
\text { full-time } \\
\text { (n:126) }\end{array}$ & $\begin{array}{l}\text { Working } \\
\text { part -time } \\
\text { (n:15) }\end{array}$ & $\begin{array}{l}\text { House } \\
\text { wife } \\
\text { (n:79) }\end{array}$ & $\begin{array}{l}\text { Retired } \\
\text { (n:45) }\end{array}$ & $\begin{array}{l}\text { Unemployed } \\
(\mathbf{n}: 11)\end{array}$ & $\mathbf{p}$ & $\mathbf{F}$ \\
\hline $\begin{array}{l}\text { Physical } \\
\text { characteristics } \\
\text { of the house }\end{array}$ & 3,46 & 3,69 & 3,48 & 3,69 & 2,209 & 0,16 & 1,62 \\
\hline $\begin{array}{l}\text { Open-green } \\
\text { areas }\end{array}$ & 2,94 & 2,66 & 3,03 & 3,19 & 2,80 & 0,45 & 0,91 \\
\hline Accessibility & 3,17 & 3,52 & 3,07 & 3,37 & 3,21 & 0,50 & 0,83 \\
\hline $\begin{array}{l}\text { Comfort } \\
\text { conditions }\end{array}$ & 3,38 & 3,88 & 3,78 & 3,40 & 3,75 & 0,62 & 2,27 \\
\hline $\begin{array}{l}\text { Social- } \\
\text { neighbourhood } \\
\text { relations }\end{array}$ & $\mathbf{3 , 3 9}$ & $\mathbf{3 , 6 4}$ & $\mathbf{3 , 9 1}$ & $\mathbf{3 , 4 2}$ & $\mathbf{3 , 5 4}$ & $\mathbf{0 , 0 4}$ & $\mathbf{2 , 4 5}$ \\
\hline
\end{tabular}

In the post-hoc test for measuring the level of satisfaction of age groups with the factors, there are significant differences in the comfort conditions factor and in the open-green areas factor. Table 8 shows that the users between the ages of 45-64 and 65-84 are more satisfied with the open -green areas factor than the users between the ages of are 18-24 and the difference with these age groups is significant. The level of satisfaction of users between the ages of 18-24 at the comfort conditions factor is higher than the users between the ages of 45-64 and 65-84. The difference between these groups' satisfaction levels is significant. In addition, the high level of satisfaction of users between the ages of 45-64 and 65-84 with open-green areas indicates that the users in these age groups spend more time outside and with the advancement of their age, they can socialize at places like parks, gardens. 
Table 8. Variance Analysis Results of Factor Groups According to the Age Range Variable

\begin{tabular}{|c|c|c|c|c|c|c|}
\hline Factors & $\begin{array}{l}18-24 \\
(n: 26)\end{array}$ & $\begin{array}{c}25-44 \\
(n: 165)\end{array}$ & $\begin{array}{l}45-64 \\
(n: 77) \\
\end{array}$ & $\begin{array}{c}65-84 \\
(n: 12) \\
\end{array}$ & $\mathbf{p}$ & $\mathbf{F}$ \\
\hline $\begin{array}{l}\text { Physical } \\
\text { characteristics of } \\
\text { the house }\end{array}$ & 3,54 & 3,41 & 3,58 & 4,06 & 0,12 & 1,95 \\
\hline $\begin{array}{l}\text { Open-green } \\
\text { areas }\end{array}$ & 2,26 & 2,91 & $\mathbf{3 , 3 0}$ & 3,23 & 0,001 & 7,22 \\
\hline Accessibility & 3,34 & 3,19 & 3,15 & 3,30 & 0,877 & 0,22 \\
\hline $\begin{array}{l}\text { Comfort } \\
\text { Conditions }\end{array}$ & 4,27 & 3,47 & 3,46 & 3,70 & 0,005 & 4,34 \\
\hline $\begin{array}{l}\text { Social- } \\
\text { neighbourhood } \\
\text { relations }\end{array}$ & 3,41 & 3,55 & 3,67 & 3,77 & 0,697 & 0,47 \\
\hline
\end{tabular}

Post-hoc test for measuring the level of satisfaction on the factor groups of the 5 mass housing users in the research area; there is significant difference between variables in open-green areas and accessibility factors. As it is seen in table 9, the satisfaction level of the users in the $5^{\text {th }}$ mass housing area is lower than the users in other mass housing areas. That the $5^{\text {th }}$ mass housing area is newly structured and its ongoing and uncompleted surrounding area arrangements explain the reason of this low satisfaction level. Significant differences especially in the open green area factor and accessibility factor support this assumption.

3rd Mass housing area started in 2005, is the only area completed in the whole mass housing area of this research. In the analysis, the satisfaction level of the 3rd mass housing area users with all factors except for open - green areas factor resulted high compared to users living in other mass housing areas. This situation proves that the users, whose construction has been completed, and who have developed neighbourhood and social relations over time, are more satisfied.

Table 9. Variance Analysis Results of Factor Groups According to Housing Area Variable

\begin{tabular}{|c|c|c|c|c|c|c|c|}
\hline Factors & $\begin{array}{l}\quad 1^{\text {st } M a s s} \\
\text { Housing } \\
\text { Area } \\
(\mathbf{n}: 63)\end{array}$ & $\begin{array}{l}2^{\text {nd } M a s s} \\
\text { Housing } \\
\text { Area } \\
(\mathbf{n}: 80)\end{array}$ & $\begin{array}{l}3^{\text {rd }} \\
\text { Mass } \\
\text { Housi } \\
\text { ng } \\
\text { Area } \\
(\mathbf{n}: 51)\end{array}$ & $\begin{array}{l}\text { 4 }^{\text {th }} \text { Mass } \\
\text { Housing } \\
\text { Area } \\
(\mathbf{n}: 61)\end{array}$ & $\begin{array}{l}5^{\text {th }} \quad \text { Mass } \\
\text { Housing } \\
\text { Area }(\mathrm{n}: 24)\end{array}$ & $\mathbf{p}$ & $\mathbf{F}$ \\
\hline $\begin{array}{l}\text { Physical } \\
\text { characteristics } \\
\text { of the house }\end{array}$ & 3,41 & 3,51 & 3,63 & 3,42 & 3,56 & 0,76 & 0,46 \\
\hline $\begin{array}{l}\text { Open-green } \\
\text { areas }\end{array}$ & 3,09 & 2,98 & 3,03 & 3,12 & 2,08 & 0,001 & 4,95 \\
\hline Accessibility & 3,30 & 3,08 & 3,46 & 3,24 & 2,69 & 0,44 & 2,35 \\
\hline $\begin{array}{l}\text { Comfort } \\
\text { conditions }\end{array}$ & 3,35 & 3,46 & 3,81 & 3,59 & 3,70 & 0,205 & 1,492 \\
\hline $\begin{array}{l}\text { Social- } \\
\text { neighbourhood } \\
\text { relations }\end{array}$ & 3,61 & 3,45 & 3,83 & 3,51 & 3,54 & 0,503 & 0,836 \\
\hline
\end{tabular}

Regression analysis was carried out to evaluate the relationship between the physical space characteristics factor, through the questions with answer options like "near, normal, far". However, since the "closenormal-far" variables are not at the interval measurement level, dummy variables were created from these variables. Since each variable has 3 groups, 2 dummy variables were obtained. In order to make comparisons, the "close" group is left out in each variable. In the multiple linear regression model; physical space characteristics are identified as dependent variables, while the variables such as distance between entrance and sitting room, distance between entrance and living room, distance between entrance and kitchen, distance between entrance and wc, distance between kitchen and sitting room and distance between bedroom and bathroom are defined as independent variables. That the $\mathrm{p}$ value of the model is less than 0.05 
indicates that the model is statistically significant. The independent variables in the model explain $21 \%$ of the change in the dependent variable $\left(\mathrm{R}^{2}\right.$ value). In the interpretation of variables' beta coefficients, standardized beta coefficients are taken into consideration. According to this model, as it is seen in Table 10, a standard deviation increase in the variable of distance between the entrance and wc (close-to-far transition) reduces the level of satisfaction with the physical space characteristics by $33 \%$. In addition, a standard deviation in the variable between kitchen and sitting room (close to far transition) reduces the satisfaction level by $16 \%$.

Table 10. Regression Analysis Results

\begin{tabular}{|c|c|c|c|c|c|}
\hline $\begin{array}{l}\text { Physical Space } \\
\text { Characteristics }\end{array}$ & B & SH & B & $\mathbf{T}$ & $\mathbf{p}$ \\
\hline $\begin{array}{l}\text { Distance between entrance } \\
\text { - sitting room (NORMAL) }\end{array}$ & $-0,006$ & 0,189 & $-0,003$ & $-0,029$ & 0,977 \\
\hline $\begin{array}{l}\text { Distance between entrance } \\
\text { - sitting room (FAR) }\end{array}$ & $-0,307$ & 0,301 & $-0,082$ & $-1,021$ & 0,308 \\
\hline $\begin{array}{l}\text { Distance between entrance } \\
\text { - living room (NORMAL) }\end{array}$ & 0,241 & 0,195 & 0,121 & 1,236 & 0,218 \\
\hline $\begin{array}{l}\text { Distance between entrance } \\
\text { - living room (FAR) }\end{array}$ & $-0,233$ & 0,292 & $-0,069$ & $-0,797$ & 0,426 \\
\hline $\begin{array}{l}\text { Distance between entrance } \\
\text {-kitchen (NORMAL) }\end{array}$ & $-0,155$ & 0,220 & $-0,079$ & $-0,706$ & 0,482 \\
\hline $\begin{array}{l}\text { Distance between entrance } \\
\text { - kitchen (FAR) }\end{array}$ & 0,254 & 0,319 & 0,068 & 0,795 & 0,427 \\
\hline $\begin{array}{l}\text { Distance between entrance } \\
\text { - wc (NORMAL) }\end{array}$ & $-0,155$ & 0,213 & $-0,079$ & $-0,726$ & 0,496 \\
\hline $\begin{array}{l}\text { Distance between entrance } \\
\text { - wc (FAR) }\end{array}$ & $-1,233$ & 0,303 & $-0,337$ & $-4,067$ & 0,001 \\
\hline $\begin{array}{l}\text { Distance between kitchen } \\
\text { - sitting room (NORMAL) }\end{array}$ & 0,221 & 0,228 & 0,112 & 0,971 & 0,333 \\
\hline $\begin{array}{l}\text { Distance between kitchen } \\
\text {-sitting room (FAR) }\end{array}$ & $-0,537$ & 0,268 & $-0,164$ & $-2,003$ & 0,046 \\
\hline $\begin{array}{l}\text { Distance between bedroom } \\
\text {-bathroom (NORMAL) }\end{array}$ & $-0,084$ & 0,207 & $-0,043$ & $-0,407$ & 0,684 \\
\hline $\begin{array}{l}\text { Distance between bedroom } \\
\text {-bathroom (FAR) }\end{array}$ & 0,571 & 0,425 & 0,122 & 1,343 & 0,180 \\
\hline $\begin{array}{l}n=280, R=0,468, R^{2}=0,21 \\
F=6,237, p<.01(0.001)\end{array}$ & & & & & \\
\hline
\end{tabular}

The answers given by all users to the 5 factor groups are given in Table 11 . When these results are taken into account, it is seen that the satisfaction level of all users with the apartment and its environment and with social relations is in general at a high level. Furthermore, evaluating the mass housing areas from a general perspective; it is observed that criteria such as location, topography, wind, and landscape were not taken into consideration. Especially the block entries built in the dominant wind direction and the way the buildings are positioned on the building blocks support this view. In addition, the size of the spaces, complies with Konya Building Bylaws. In the analysis examining the sufficiency of room numbers, the users indicated that the number of rooms was sufficient by choosing "I agree" answer at the rate of 52\%. The users found the distances between spaces in the apartment to be "Normal" by approximately $51 \%$. The use of night halls in many apartments has an effect that increases the level of privacy. In order to ensure visual control especially in bedrooms, the use of night halls is considered as a positive side. 
Table 11. Percentage of Participants' Responses to Factor Groups

\begin{tabular}{llllll} 
& $\begin{array}{l}\text { I } \\
\text { strongly } \\
\text { agree }\end{array}$ & I agree & $\begin{array}{l}\text { Neither } \\
\text { agree or } \\
\text { disagre } \\
\text { e }\end{array}$ & $\begin{array}{l}\text { I don't } \\
\text { agree }\end{array}$ & $\begin{array}{l}\text { Strongly } \\
\text { disagree }\end{array}$ \\
\hline $\begin{array}{l}\text { Physical Space } \\
\text { Characteristics }\end{array}$ & $\% 8,2$ & $\% 51,2$ & $\% 7,6$ & $\% 13,0$ & $\% 10,8$ \\
\hline $\begin{array}{l}\text { Open-green } \\
\text { area }\end{array}$ & $\% 12,4$ & $\% 33,8$ & $\% 14,15$ & $\% 17,9$ & $\% 21,6$ \\
\hline $\begin{array}{l}\text { Accessibility } \\
\text { Comfort } \\
\text { conditions }\end{array}$ & $\% 12,4$ & $\% 41,86$ & $\% 16,06$ & $\% 12,8$ & $\% 16,8$ \\
\hline $\begin{array}{l}\text { Social- } \\
\text { neighbourhood } \\
\text { relations }\end{array}$ & $\% 21,35$ & $\% 46,6$ & $\% 11,08$ & $\% 6,8$ & $\% 13,3$ \\
\hline
\end{tabular}

It was observed that there was no problem related with the heating, since jacketing was done in mass housing areas. To questions covering these matters, $20 \%$ of the participants replied, "I strongly agree", and about $45 \%$ replied "I agree". However, in some blocks, necessary precautions are not taken for apartments facing north and this is considered as a negative side.

Mass housing areas are located close to the city centre. As a result of the transport analysis, it was observed that a large number of public transport vehicles passes around these areas at certain times of the day. The answers given by the users to the questions related with accessibility factor in the survey study prove this situation.

In the analysis examining the type of houses the users were living in before the mass housing areas, the results revealed the apartment with the highest rate. Then comes the single-storey house, residence campus and shanty house.

Since 100 participants living in shanty houses and single-storey houses before living in the mass housing of the research area were accustomed to the neighbourhood culture and had a closer relationship with the land, their satisfaction level with sufficiency and quality of open-green areas and with socialneighbourhood relationships was expected to result as low, compared to other participant groups. However, since the $\mathrm{p}$ value in the t-test was higher than 0.05 , a significant difference could not be revealed and this assumption could not be confirmed.

\section{RESULT}

This study aims to give an insight and an idea to future housing projects, by measuring the satisfaction level of users living in mass housing areas built under the leadership of local administrations as an effort to provide housing. The municipality led 22 mass housing projects between the years of 2004 and 2015 and approximately 27 thousand people live in these mass housing areas. The municipality aimed to solve the housing problem by giving the opportunity to acquire a house to such a high population. In line with this goal, many people who have not taken the opportunity to own a house in their lifetime were given the possibility to acquire a house. However, at the project planning and designing phase, the municipality did not perform any analysis to identify the user needs.

These projects are very important because they seriously interfere with the urban fabric and identity. The involvement of public in the project planning phase will give the users the chance to express their needs, thus will give rise to more qualified and user-participating projects in the future. With the links to be established with the universities and the working groups to be formed by academicians, these projects can be explained to local people. This kind of activities would increase the awareness significantly on this subject. Moreover, the encouraging power of architectural competitions is an undeniable fact under today's conditions. The architectural competitions to be launched would enable the architects to have a word in mass housing projects that affect the city so much. 
The satisfaction of the users of these buildings determines the quality of life here, thus it affects the liveability of the area for many years. The information gained from the study indicates that the green area and accessibility factors affect user satisfaction highly. Therefore particular attention should be paid to this issue in the design of residential areas. Green areas have many benefits for urban ecology, such as temperature balancing, oxygen production, noise reduction and humidity balancing. In addition, it is beneficial to human psychology. Being in close relation with nature reduces the stress of city life and relaxes people psychologically. As the quality and quantity of these areas decrease, the positive effect of them on people decreases. With the increasing urban population, environmental pollution increases and the amount of green areas per capita decreases. In such an environment, the city landscape should serve to a sustainable ecology and be planned systematically. Since the mass housing areas and their surroundings occupy a very large area in the cities, the green area planning in these projects is very important for the cities. Green areas remain to be a matter which is neglected in the projects whose priority is to build buildings. For this reason, for a sustainable city, it is essential to plan green areas and to carry out serious studies with necessary expertise on this subject. Furthermore, in the planning of mass housing areas, the relationship of these areas with public transport networks and their connection to main arteries should be addressed especially at the planning stage.

It has been accepted in many platforms that every individual has the right to live in a liveable environment and in a quality house. The creation of liveable environments and the transformation of the houses into more qualified building groups rather than high quantity should be indispensable for individuals with all kinds of social degrees. Practices where the houses are expressed only in numbers and the concepts such as the quality of the house are ignored, can not ensure the individuals' satisfaction with the house sufficiently.

As a result of the study, it is observed that in the residences where spatial organization is improved, the user satisfaction is increased, but an important factor of satisfaction is also determined by social relations. In order for individuals to "realize themselves" psychologically, meeting their physiological needs is not enough. If you look from the general framework of the residential buildings in the study area, the satisfaction levels are on a high average. However, with another study to be carried out in the coming years, the effect of changing living standards, environmental conditions and housing standards can make a difference. Therefore, in the planning phases, decisions should be taken from a wider and longer perspective.

\section{CONFLICTS OF INTEREST}

No conflict of interest was declared by the authors.

\section{REFERENCES}

[1] Erten Bilgiç, D., "Kentleşme sürecinde konut olgusunun geçirdiği değiş̧imler çerçevesinde Yukarı Değirmendere- Çarşiiçi Mahallesi örneği”, Megaron, 3(1): 1-15, (2008).

[2] Es, M., Ateş, H., "Kent yönetimi, kentlileşme ve göç: sorunlar ve çözüm önerileri”, Journal of Social Policy Conferences, 0(48): 205-248, (2010).

[3] Ekinci, C., Susmaz, H., "Sağl1kl1 kentlesme süreci esasları" Social Sciences, 4(1): 21-34, (2009).

[4] Tmmob Kentleşme ve Yerel Yönetimler Çalışma Grubu, "Kaçak yapılaşma ile ilgili süreçler, sorunlar, çözüm önerileri” Değerlendirme Raporu, (2004).

[5] Özsoy, A., “Toplu konut uygulamalarının gelişimi-bir değerlendirme”, Eko Yapı Dergisi, 3: 42-46, (2011).

[6] Karakaş, B., "Seçilmiş Avrupa ülkelerinde sosyal konut uygulamaları", İş ve Hayat, 1(2): 47$68,(2015)$. 
[7] Kundurac1, N.F., "Dünyada ve Türkiye'de sosyal konut uygulamaları", Çağdaş Yerel Yönetimler, 22(3): 53-77, (2013).

[8] Tapan, M., “Toplu Konut ve Türkiye'deki Gelişimi”, Y. Sey (Der), Tarihten Günümüze Anadolu' da Konut ve Yerleşme, İstanbul Tarih Vakfı Yayını, 366-378, (1996).

[9] Tekeli, İ., “Türkiye'de Cumhuriyet Döneminde Kentsel Gelişme ve Kent Planlaması”, 75 Yılda Değişen Kent ve Mimarlık, Tarih Vakfi Yayınları, (1998).

[10] Çakır, S., "Türkiye'de göç, kentleşme/gecekondu sorunu ve üretilen politikalar”, SDÜ Fen Edebiyat Fakültesi Sosyal Bilimler Dergisi, 23: 209-222, (2011).

[11] Şenyapıl1, T., Cumhuriyet'in 75. Y1lı Gecekondunun 50. Y11, 75 Yılda Değişen Kent ve Mimarlık, Bilanço'98, Tarih Vakfı Yayınları, lstanbul, 301-316, (1998).

[12] https://www.toki.gov.tr/AppResources/UserFiles/files/FaaliyetOzeti/ozet.pdf Access date: 03.01 .2018

[13] Bruning, S.D., Langenhop, A., Green, K.A., "Examining city-resident relationships: linking community relations, relationship building activities, and satisfaction evaluations", Public Relations Review, 30: 335-345, (2004).

[14] Anthony, K.H, Weidemann, S., Chin, Y., "Housing perception of low-income single parents", Enviroment and Behavior, London., 22(2): 147-182, (1990).

[15] Kellekci, Ö.L., "Kullanıcıların Konut ve Çevresel Kalite Memnuniyetinin Belirleyicileri: İstanbul Metropoliten Alan Örneği.” Doktora Tezi, İTÜ, Fen Bilimleri Enstitüsü, İstanbul, (2005).

[16] Türkoğlu, H.D., "Residents satisfaction of housing environments: the case of Istanbul, Turkey" Landscape and Urban Planning, 39(1): 55-67, (1997).

[17] Gür, M., Dostoğlu, N., "Bursa Doğanbey üzerinden kentsel dönüşümde yaşam kalitesinin tartışılması,” Megaron Journal, 11(1): 89-105, (2016).

[18] Lee, J., Cheong, S., Shin, S., "A Study on residential quality index of super high-rise apart ment housing through survey with experts", International Conference on Sustainable Building Asia, 899-904, (2007).

[19] Gür, M., Dostoğlu, N., "Bursa' daki alt ve orta gelire yönelik TOKİ konutlarında memnuniyet araştırması", Uludağ Üniversitesi Mühendislik-Mimarlık Fakültesi Dergisi, 15(2): 139-153, (2010).

[20] Berköz, L., “İstanbul'da korunaklı tek-aile konutları: konut kalitesi ve kullanıcı memnuniyetinin belirlenmesi”, İTÜ Dergisi/a, Mimarlık Planlama Tasarım, 7(1): 110-124, (2008).

[21] Yılmaz Çakmak, B., Kırsaldan Kente Göç İle Kent Çeperlerinde Oluşan Konutların Mekansal Dizim Yöntemiyle Analizi, Doktora Tezi, Selçuk Ünv., Konya, (2011).

[22] https://www.karatay.bel.tr/karatay.html Access date: 2017 